\title{
173. Quantitative Precipitin Studies on Catalase Protein in Hemolysate and Acetone Extract from Acatalasemia and Hypocatalasemia
}

\author{
By Masana OGata*) and Shigeo TAKahara**) \\ Okayama University Medical School, Okayama \\ (Comm. by T. Furuhata, M.J.A., Dec. 12, 1962)
}

Introduction. Recently it is well recognized that acatalasemia is a congenital abnormality whose blood has no catalase activity and hypocatalasemia ${ }^{1)}$ showing one half catalase activity of normal blood is heterozygous or genetic carrier state of acatalasemic gene.

In the previous papers ${ }^{23)}$ we described that catalase protein could not be found in the extract (stages 2 and 3 by Herbert-Pinsent) of acatalasemic blood when examined by paper electrophoretic, ${ }^{3)}$ spectrophotometric ${ }^{4)}$ and immunological methods. ${ }^{2)}$ However, in the above experiments there is a possibility that some denatured catalase protein might have moved from the extract to the sediment when treated with ethanol-chloroform mixture. To make this point clear, we carried out the following experiments using the normal, hypocatalasemic and acatalasemic hemolysates themselves as the antigen and estimated the quantity of catalase protein in their blood by means of quantitative precipitin method. Also acetone extracts obtained from the normal, hypocatalasemic and acatalasemic blood were used as the antigen for the quantitative estimation of catalase protein.

Materials. Blood. The heparinized blood taken from the cubital vein of normal and acatalasemic individuals was used.

Hemolysate. The red blood cells were separated from heparinized human blood by centrifugation and washed three times with physiological saline solution. The cells were hemolyzed by distilled water, 3 volumes of cell amount, and after their stroma was precipitated by centrifugation with the gravity of 18,000 , the precipitate was discarded. In order to make the supernatant isotonic to the normal human serum, $1 \mathrm{ml}$ of 9.0 per cent saline solution was added to $10 \mathrm{ml}$ of the supernatant and this mixture was used as antigen.

Acetone Extract. The separation and washing of red blood cells were handled in the same manner as above. The cells were laked in distilled water, 2 volumes of cell amount, and then acetone, 0.8 volumes of laked blood suspension, was added on. After further

*) Professor, Department of Public Health.

**) Professor, Department of Oto-Rhino-Laryngology.

This work was supported by a grant-in-aid from the Rockefeller Foundation (RF 60102). 
centrifugation of the above suspension, hemoglobin was discarded as precipitate. To collect catalase in the supernatant, acetone solution was further added to the above supernatant, until the precipitation completed. After centrifugation of this solution the precipitated substance was freeze-dried in powder in a vacuum chamber. After dissolving this powder in saline solution, the insoluble material was precipitated by centrifugation and the clear supernatant having catalase activity was used as antigen for the test.

Anticatalase Rabbit Serum. As to induce antibody, $1 \mathrm{ml}$ of Freund's adjuvant, which was made to contain $2.0 \mathrm{mg}$ purified human catalase (stage 5 by Herbert-Pinsent) per unit amount (ml), was injected intramuscularly to rabbit weekly for 10 weeks. One week after the last injection, the blood was taken by cardiac puncture and the serum was used as human catalase antibody.

Methods. Quantitative Precipitin Test. In order to make the standard quantitative precipitin curve, $1 \mathrm{ml}$ of the solution of purified catalase (stage 5 by Herbert-Pinsent) in various concentrations was added to $1 \mathrm{ml}$ anticatalase rabbit serum in test tube.

These test tubes were kept at $37^{\circ} \mathrm{C}$ for one hour, and then placed in a refrigerator at $4-10^{\circ} \mathrm{C}$ for 12 hours. The antigen-antibody precipitate obtained by centrifugation was washed three times with cold physiological saline solution. For the quantitative determination of protein in the precipitate, the method described by Heidelberger and MacPherson, ${ }^{5)}$ utilizing Folin-Ciocalteu's reagent, was used. Thirty minutes after the addition of Folin-Ciocalteu's reagent to the precipitate, optical density of blue coloration was checked with a Beckman type spectrophotometer at the wave length of $700 \mathrm{~m} \mu$ and tyrosine content was calculated from the above optical density value referring to the optical density of blue coloration of standard tyrosine solution. Then nitrogen quantity of precipitate was determined by the following formula: nitrogen quantity = tyrosine content $\times 14.4 \times 0.16$. Next, the quantitative precipitin curve was drawn by joining several points, each of which was obtained by plotting intersection of two axes indicating the nitrogen amount of purified catalase and that of corresponding precipitate.

For quantitative analysis of catalase protein using the above standard curve, one $\mathrm{ml}$ of normal, hypocatalasemic and acatalasemic hemolysates as well as acetone extract was added to one $\mathrm{ml}$ of the rabbit catalase antibody. In the similar manner as described above, optical density value of these precipitates was checked and converted into nitrogen value, then it was plotted on the ordinate axis. From this point a horizontal line was extended to the standard curve and from the intersection a vertical line is drawn to the abscissa. The 
distance from the point of the abscissa to the original point represents the nitrogen amount of catalase protein in antigen solution.

Results. Quantitative Precipitin Curve between Purified Catalase and its Rabbit Antibody. Fig. 1 demonstrates the quantitative precipitin curve of purified human catalase against anticatalase rabbit serum. As in the case of bovine liver catalase, relationship between nitrogen amount of antibody and that of antigen precipitated did not follow the Heidelberger and Kendall's equation. So the antibody/ antigen ratio at the maximum precipitation zone was calculated directly from the nitrogen quantity of antibody and antigen (purified catalase) in the curve shown in Fig. 1, and it was $0.52 \mathrm{mg} \mathrm{N} /$ $0.12 \mathrm{mg} N=4.4$. This value was equal to that (4.4) calculated from the catalase molecular weight $\left(23.6 \times 10^{4}\right)$ and rabbit antibody molecular weight $\left(14.0 \times 10^{4}\right)$ with the use of Boyd and Hooker's formula.

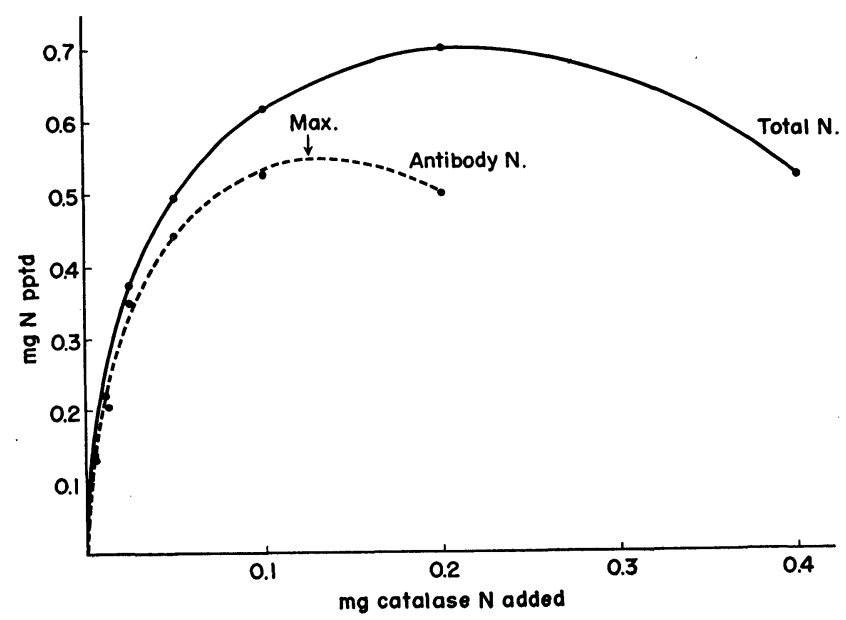

Fig. 1. Quantitative precipitin curve of purified catalase (stage 5) with its rabbit antibody.

Catalase Protein Amount in Normal, Hypocatalasemic and Acatalasemic Hemolysates. Fig. 2 illustrates the reaction of hemolysate against anticatalase rabbit serum using quantitative precipitin curve shown in Fig. 1. Symbols, Normal, Hypo., and A in Fig. 2 represent the nitrogen quantity of precipitate between the catalase antibody and hemolysates of normal, hypocatalasemic and acatalasemic blood. $\mathrm{N}^{\prime}, \mathrm{H}^{\prime}, \mathrm{A}^{\prime}$, each of them indicates the nitrogen quantity of antigen catalase measured from the quantitative precipitin curve. The ratio of quantity of catalase protein in normal, hypocatalasemic and acatalasemic hemolysates was $1.0: 0.5: 0.07$, while the catalase activity showed nearly the same ratio of $1.0: 0.5: 0$. These results coincide with the macroscopic findings in the above antigen-antibody reaction. 


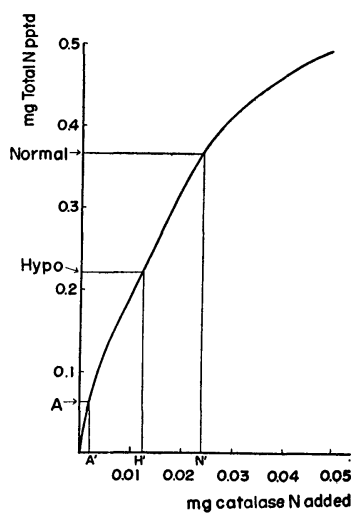

Fig. 2. Reaction of normal, hypocatalasemic, acatalasemic hemolysate with anti-human red blood cell catalase rabbit serum.

Normal $=$ precipitate due to normal hemolysate.

Hypo = precipitate due to hypo-

A catalasemic hemolysate. $=$ precipitate due to acatalasemic hemolysate.

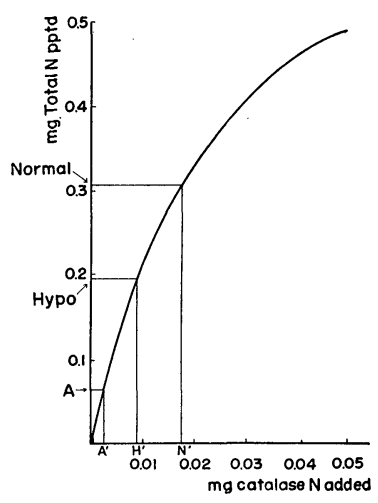

Fig. 3. Reaction of normal, hypocatalasemic, acatalasemic acetone extract with anti-human red blood cell catalase rabbit serum.

Normal $=$ precipitate due to normal acetone extract.

Hypo = precipitate due to hypocatalasemic acetone extract.

A = precipitate due to acatalasemic acetone extract.

Namely, turbidity observable when hypocatalasemic hemolysate is added to catalase antibody, is less than that in the case of normal hemolysate against catalase antibody. When acatalasemic hemolysate is added to catalase antibody, turbidity can hardly be recognized.

Catalase Protein Amount in Normal, Hypocatalasemic and Acatalasemic Acetone Extracts. Fig. 3 also shows the reaction of acetone extract with catalase antibody. Symbols, Normal, Hypo., and A represent nitrogen quantity of precipitates in the reaction with normal, hypocatalasemic and acatalasemic acetone extracts and $\mathrm{N}^{\prime}, \mathrm{H}^{\prime}, \mathrm{A}^{\prime}$, each of them indicates catalase nitrogen quantity of acetone extract, respectively. The ratio of catalase protein in normal, hypocatalasemic and acatalasemic extracts shows $1.0: 0.49: 0.11$, while the ratio of catalase activities is $1.0: 0.47: 0$.

From the results shown in Figs. 2 and 3, it is to be noted that the quantity and activity of catalase are always parallel even in the hemolysate and acetone extract. Tables I and II illustrate the detailed data concerning Figs. 1, 2, and 3.

Precipitin Ring Test between Acetone Extract and Catalase Antibody. Table III shows the findings in the ring test which was conducted between catalase antibody and acetone extracts of normal, hypocatalasemic and acatalasemic blood. In the normal and hypocatalasemic extracts the precipitin ring was found to be positive until $1: 40$ and $1: 20$ dilution of original solution respectively. In 
Table I. Precipitin reaction of purified catalase against its rabbit antibody for drawing the standard quantitative precipitin curve

\begin{tabular}{c|c|c|c}
\hline $\begin{array}{c}\text { Amount of } \\
\text { antigen N }\end{array}$ & $\begin{array}{c}\text { Total N } \\
\text { precipitated }\end{array}$ & $\begin{array}{c}\text { Antibody N } \\
\text { (total N-antigen N) }\end{array}$ & $\begin{array}{c}\text { Ratio of antibody } \\
\text { N to antigen N }\end{array}$ \\
\hline $0.006^{\mathrm{mg}}$ & $0.136^{\mathrm{mg}}$ & $0.130^{\mathrm{mg}}$ & 21.7 \\
0.012 & 0.219 & 0.207 & 17.3 \\
0.025 & 0.374 & 0.349 & 13.9 \\
0.050 & 0.496 & 0.446 & 8.9 \\
0.100 & 0.621 & 0.521 & 5.2 \\
0.200 & 0.701 & 0.501 & 2.5 \\
0.400 & 0.527 & 0.127 & 0.3 \\
\hline
\end{tabular}

Table II. Nitrogen quantity of antigen catalase measured from the quantitative precipitin curve (Fig. 1)

\begin{tabular}{l|c|c}
\hline \multicolumn{1}{c|}{ Antigen } & $\begin{array}{c}\text { Total } \\
\text { precipitated }\end{array}$ & $\begin{array}{c}\text { Amount of antigen N measured } \\
\text { from the quant. prec. curve }\end{array}$ \\
\hline Normal hemolysate & $0.365^{\mathrm{mg}}$ & 0.024 \\
Hypo. hemolysate & 0.221 & 0.012 \\
Acat. hemolysate & 0.062 & 0.002 \\
\hline \hline Normal acetone ext. & 0.309 & 0.018 \\
Hypo. acetone ext. & 0.199 & 0.009 \\
Acat. acetone ext. & 0.065 & 0.002 \\
\hline
\end{tabular}

Table III. Precipitin ring test of normal, hypocatalasemic and acatalasemic acetone extract with anti-human catalase rabbit serum

\begin{tabular}{|c|c|c|c|c|c|c|}
\hline Antigen dilution & 5 & 10 & 20 & 40 & 80 & 160 \\
\hline Normal extract & Wl & 冊 & H & + & - & - \\
\hline Hypocatalasemic extract & 冊 & H & + & - & - & - \\
\hline Acatalasemic extract & - & - & - & - & - & - \\
\hline
\end{tabular}

the case of acatalasemic extract, no precipitin ring was observed.

Discussion. From the previous experiments by the method of paper electrophoresis ${ }^{3)}$ and immunological reaction, ${ }^{2)}$ we assumed that catalase protein does not exist in acatalasemic extract (stages 2 and 3 by Herbert-Pinsent) and the absence of catalase activity is due to the lack of catalase protein itself. In this experiment we confirmed further the above belief by the results of quantitative precipitin test using hemolysate and acetone extract of acatalasemic blood.

As to the deficiency of catalase protein in acatalasemic blood, the following interpretations may be raised. Generally it has been thought that the gene responsible for catalase formation gives information for the catalase protein templates. In the case of acatalasemia, acatalasemic gene having probable alteration of DNA calls 
for the extremely high structural change of template and consequently the errors in the biosynthesis of catalase protein will be caused.

At present phenylketonuria, tyrosinosis, alkaptonuria, albinism, and galactosemia are well recognized as the genetic diseases because of their deficiency of enzyme activity. Among these inborn errors of metabolism, acatalasemia is the only one which can be proved to be lacking enzyme protein. Furthermore, it should be noted that other than hypocatalasemia there has been no significant example of heterozygote showing clearly one half of enzyme activity due to one half of enzyme protein.

In any event, the results of our several approaches to solve the problems of catalase protein in acatalasemic and hypocatalasemic blood will present some suggestions for the concept of genetical control in enzyme synthesis.

Conclusion. 1) The ratio of catalase quantity in normal, hypocatalasemic and acatalasemic blood, calculated from precipitates produced in the reaction between catalase antibody and hemolysates was $1.0: 0.5: 0.07$.

2) The ratio of catalase quantity in normal, hypocatalasemic and acatalasemic blood, calculated from precipitates between the catalase antibody and the acetone extract was $1.0: 0.49: 0.11$. In the precipitin ring tests using acetone extract the ratio of antigen titer in normal, hypocatalasemic and acatalasemic extracts was $40: 20: 0$, as shown in Table III.

3) From our experiments it can be said that hypocatalasemic blood shows one half catalase activity of normal blood, due to one half quantity of catalase protein, and acatalasemic blood lacks catalase activity due to no catalase protein. These findings strongly suggest that there exist no substances suppressing or inhibiting the catalase activity in these bloods.

\section{References}

1) Takahara, S., Hamilton, H. B., Neel, J. V., Kobara, T. Y., Ogura, Y., and Nishimura, E. T.: J. Clin. Invest., 39, 610 (1960).

2) Takahara, S., Ogata, M., Kobara, T. Y., Nishimura, E. T., and Brown W. J.: Lab. Invest., 11, 782 (1962).

3) Ogata, M., and Takahara, S.: Proc. Japan Acad., 38, 361 (1962).

4) Takahara, S., and Ogata, M.: Proc. Japan Acad., 38, 779-782 (1962).

5) Heidelberger, M., and MacPherson, C. F. C.: Science, 97, 405 (1943). 